\title{
ANALISIS KEMAMPUAN PEMAHAMAN KONSEP MATEMATIS SISWA DALAM MENYELESAIKAN SOAL PADA MATERI BILANGAN BULAT KELAS VII SMPN 19 KOTA JAMBI
}

\author{
Monalisa $^{1}$, Harman $^{2}$, Ayu Yarmayani ${ }^{3}$ \\ Program Studi Pendidikan Matematika, FKIP, Universitas Batanghari ${ }^{1,2,3}$ \\ Jl. Slamet Riyadi No.1 Broni Jambi \\ Email : -
}

\begin{abstract}
ABSTRAK
Kemampuan pemahaman konsep matematis merupakan salah satutujuan umum dari pembelajaran matematika di sekolah. Kemampuan ini sangat penting bagi siswa karena membantu siswa dalam memahami dan mengaplikasikannya dalam kehidupan sehari-hari. Pemahaman konsep matematis siswa di SMPN 19 Kota jambi sangat bervariasi sehingga belum diketahui bagaimana kemampuan pemahaman konsep yang dimiliki siswa kelas VII SMPN 19 Kota jambi. Penelitian ini bertujuan untuk mendeskripsikan bagaimana kemampuan pemahaman konsep matematis siswa dalam enyelesaikan soal pada materi bilangan kelas VII SMPN 19 Kota jambi untuk setiap indikator dan secara keseluruhan. Jenis penelitian yang digunakan dalam penelitian ini adalah penelitian kualitatif yang bersifat deskriptif. Pemilihan subjek pada penelitian ini menggunakan teknik purposive sampling yaitu siswa kelas VII SMPN 19 Kota jambi tahun pelajaran 2018/2019 dijadikan sebagai subjek. Instrumen pada penelitian ini adalah tes kemampuan pemahaman konsep matematis dan pedoman wawamncara. Teknik pengumpulan data dalam penelitian ini penulis lakukan dengan triangulasi teknik. Berdasarkan hasil penelitian dapat diketahui pada indikator menyatakan ulang sebuah konsep berada pada presentase $70 \%$, pada indikator menyajikan konsep dalam berbagai representasi berada pada presentase 45,55\%, indikator memberikan contoh atau kontra contoh dari konsep yang telah mereka pelajari pada presentase $65,55 \%$, indikator menerapkan konsep secara algoritma berada pada presentase $50 \%$ dan pada indikator mengaitkan berbagai konsep matematika secara internal dan eksternal berada pada presentase $61,11 \%$. Secara keseluruhan kemampuan pemahaman konsep pada materi perbandingan siswa kelas VII SMPN 19 Kota jambi tahun pelajaran 2017/2018 berada pada kualifikasi masih kurang
\end{abstract}

\section{Kata kunci :}

Kemampuan Pemahaman Konsep Matematis, Bilangan Bulat

\begin{abstract}
The ability to understand mathematical concepts is one of the general objectives of learning mathematics in schools. This ability is very important for students because it helps students understand and apply it in everyday life. Understanding of the mathematical concepts of students at SMPN 19 Jambi City varies greatly so that it is not yet known how the ability to understand the concepts possessed by VII grade students of SMPN 19 Jambi City. This study aims to describe how the students' ability to understand mathematical concepts in solving problems in grade VII material at SMP 19 Kota Jambi for each indicator and as a whole. This type of research used in this research is descriptive qualitative research. The selection of subjects in this study used a purposive sampling technique, namely VII grade students of SMPN 19 Jambi City in 2018/2019 academic year as subjects. The instrument in this study was a test of the ability to understand mathematical concepts and guidelines for interview. Data collection techniques in this study the authors do with triangulation techniques. Based on the results of the study can be seen in the indicator restate a concept is at a percentage of $70 \%$, the indicator presents the concept in a variety of representations at a percentage of $45.55 \%$, the indicator provides examples or counter examples of concepts they have learned at a percentage of $65.55 \%$, indicators applying the algorithmic concept are at $50 \%$ percentage and the indicators linking various mathematical concepts internally and externally are at $61.11 \%$ percentage. Overall, the ability to understand the concepts in the comparative material for VII grade students of SMPN 19 Jambi City in the academic year 2017/2018 is still lacking in qualifications
\end{abstract}

Keywords :

Ability to understand mathematical concepts, integers 


\section{$\pi$ (Phi)}

\section{PENDAHULUAN}

Matematika merupakan salah satu mata pelajaran yang ada di sekolah. Yang harus dikuasai oleh siswa pada jenjang pendidikan sekolah dasar sampai sekolah menengah atas. Hal ini menunjukkan bahwa matematika merupakan mata pelajaran yang memiliki kedudukan penting, karena matematika merupakan bidang studi yang amat berguna dan banyak memberi bantuan dalam berbagai disiplin ilmu yang lain. Oleh karena itu maka dapat dikatakan setiap orang memerlukan pengetahuan matematika dalam berbagai bentuk sesuai dengan kebutuhannya.

Menurut Susanto (2013:183) matematika berkenaan dengan ide-ide dan konsep yang abstrak dan tersusun secara sistematis. Karena konsep matematika yang tersusun secara sistematis, maka dalam belajar matematika tidak boleh ada langkah/tahapan yang dilewati. Sebab itulah, matematika hendaknya dipelajari secara sistematis dan disajikan dengan struktur yang jelas dan harus disesuaikan dengan perkembangan intelektual siswa.

Matematika memiliki beberapa unit yang satu sama lain saling berhubungan, maka yang penting dalam belajar matematika adalah bagaimana kemampuan seseorang dalam memahami konsep matematika. Kenyataan di lapangan siswa hanya menghafal rumus yang sudah ada dan kurang mampu mengaitkan asal mula rumus tersebut dengan konsep yang dimiliki. Telah diketahui bahwa semua materi matematika yang ada di sekolah mengandung aspek pemahaman konsep, karena kemampuan mendasar dalam belajar matematika adalah memahami konsep terlebih dahulu. Secara umum siswa sering mengalami kesulitan dalam kegiatan pembelajaran matematika, ini disebabkan karena kurangnya siswa dalam memahami konsep-konsep yang ada dalam pelajaran matematika (Fitriani, 2015; Fitriani, 2016)

Pentingnya pemahaman konsep matematika terlihat dalam tujuan pertama pembelajaran matematika menurut
Depdiknas (Permendiknas No.22 tahun 2006) yaitu memahami konsep matematika, menjelaskan keterkaitan antara konsep dan mengaplikasikan konsep atau algoritma secara luwes, akurat, efisien dan tepat dalam pemecahan masalah. Sesuai dengan tujuan pembelajaran matematika di atas maka setelah proses pembelajaran siswa diharapkan dapat memahami suatu konsep matematika sehingga dapat menggunakan kemampuan tersebut dalam menghadapi masalah-masalah matematika.

Kemampuan pemahaman konsep matematis merupakan salah satu tujuan umum dari pembelajaran matematika di sekolah. Kemampuan ini sangat penting bagi siswa karena membantu siswa dalam memahami dan mengaplikasikannya dalam kehidupan sehari-hari. Memahami setiap konsep yang diberikan, siswa akan lebih mudah dalam menyelesaikan masalah dan mengaitkannya dengan pengetahuanpengetahuan yang dimiliki siswa sebelumnya. Jika sebaliknya, siswa yang kurang memahami kesulitan dalam mengaplikasikan konsep tersebut dalam pemecahan masalah.

Berdasarkan hasil observasi di SMPN 19 Kota Jambi, mata pelajaran matematika kelas VII SMPN 19 kota jambi bahwa kemampuan pemahaman konsep matematis siswa pada awal pembelajaran masih kurang dalam memahami konsep matematika dengan baik. Masalah terutama terhadap tingkat kemampuan pemahaman siswa dalam penyelesaian soal matematika.

Dalam pembelajaran matematika yang berkaitan dengan kemampuan pemahaman konsep siswa masih mengalami kesulitan dalam menyelesaikan soal-soal yang diberikan oleh guru misalnya kesulitan dalam menerapkan rumus matematika dan belum mampu menguatkan ide-ide matematika untuk menemukan solusi pemecahan masalah matematika dari soal yang diberikan. Masalah lain yang ditemukan pada saat pembelajaran adalah siswa tidak aktif selama mengikuti pembelajaran. Kebanyakkan siswa belum 


\section{$\pi$ (Phi)}

memahami materi dengan baik tetapi tidak mau bertanya kepada guru sehingga siswa mengalami kesulitan dalam mengerjakan soal-soal yang diberikan.

\section{METODE PENELITIAN}

Penelitian ini termasuk jenis penelitian yang menggunakan metodologi penelitian kualitatif deskriptif. Menurut Arikunto (2014:3) istilah deskriptif berasal dari istilah bahasa inggris "to describe" yang berarti memaparkan atau menggambarkan sesuatu hal, misalnya keadaan, kondisi, situasi, peristiwa, kegiatan, dan lain-lain. Dengan demikian yang dimaksud dengan penelitian deskriptif ialah penelitian yang dimaksudkan untuk menyelidiki keadaan, kondisi atau halhal lain yang sudah disebutkan, yang hasilnya dipaparkan dalam bentuk laporan penelitian.

Penelitian deskriptif umumnya hanya memaparkan gambaran yang terjadi pada fenomena yang dalam hal ini adalah kegiatan yang diteliti, kemudian diambil kesimpulan. Penelitian deskriptif menghasilkan data berupa kata-kata tertulis atau lisan dan tidak berupa angka-angka. Penelitian ini akan dilaksanakan pada siswa kelas VII SMP Negeri 19 Kota Jambi. Hal yang dideskripsikan dalam penelitian ini adalah analisis kemampuan pemahaman konsep matematis siswa dalam menyelesaikan soal materi bilangan bulat. Pendeskripsian ini ditelusuri melalui pengamatan langsung terhadap subjek penelitian yaitu dengan mengamati langkahlangkah yang dikerjakan oleh subjek penelitian dalam menyelesaikan soal. Pendeskripsian ini juga dilakukan dengan cara wawancara semi terstruktur kepada subjek penelitian. Wawancara bertujuan untuk mengungkapkan kemampuan pemahaman konsep matematis siswa dalam menyelesaikan soal materi bilangan bulat.

Penelitian ini di laksanakan di SMP Negeri 19 Kota Jambi kelas VII tahun ajaran 2018/2019. Waktu penelitian dilaksanakan pada semester ganji tahun ajaran 2018/2019.
Pengumpulan data dilakukan pada siswa kelas VII SMP Negeri 19 Kota Jambi.

Menurut Arikunto (2010:172) yang dimaksud sumber data dalam penelitian adalah subjek dari mana data diperoleh. Teknik pemilihan subjek dalam penelitian ini adalah teknik purposive sampling. Menurut Sugiyono (2013:300) purposive sampling adalah teknik pengambilan subjek sumber data dengan pertimbangan dan tujuan tertentu. Berdasarkan definisi tersebut maka yang menjadi sumber data dalam penelitian ini adalah siswa kelas VII SMP Negeri 19 Kota Jambi semester ganjil tahun ajaran 2018/2019. Subjek yang diwawancarai dalam penelitian ini adalah siswa tingkat kemampuan pemahaman konsep matematis tinggi, siswa tingkat kemampuan pemahaman konsep matematis sedang, dan siswa kemampuan pemahaman konsep matematis rendah.

Menurut Sugiyono (2007:225) teknik pengumpulan data dapat dilakukan dengan observasi, wawancara, dokumentasi dan gabungan/triangulasi. Teknik pengumpulan data dalam penelitian ini penulis lakukan dengan cara gabungan/triangulasi. Menurut Sugiyono (2007:241) triangulasi diartikan sebagai teknik pengumpulan data yang bersifat menggabungkan dari berbagai teknik pengumpulan data dan sumber data yang telah ada. Teknik pengumpulan data dengan cara triangulasi, sebenarnya peneliti mengumpulkan data sekaligus menguji kredibilitas data.

Teknik pengumpulan data merupakan langkah yang paling strategis dalam penelitian, karena tujuan utama dari penelitian adalah mendapatkan data. Tanpa mengetahui teknik pengumpulan data, maka peneliti tidak akan mendapatkan data yang memenuhi standar data yang ditetapkan.

Teknik pengumpulan data yang dilakukan dalam penelitian ini dilakukan dengan memberikan tes kemampuan pemahaman konsep matematis siswa dalam menyelesaikan soal materi bilangan bulat yang terdiri dari 5 soal. Setelah siswa 


\section{$\pi$ (Phi)}

melakukan tes kemampuan pemahaman konsep siswa, peneliti menentukan subjek berdasarkan tingkat kemampuan pemahaman konsep yaitu tinggi, sedang dan rendah. Selanjutnya subjek yang sudah terpilih dilakukan wawancara. Wawancara yang dilakukan oleh peneliti adalah wawancara semiterstruktur. Wawancara ini dilakukan untuk mengetahui kemampuan pemahaman konsep yang dialami oleh subjek dalam menyelesikan soal materi bilangan bulat. Wawancara dilakukan untuk setiap nomor soal pada lembar tes tersebut. Setelah data terkumpul, selanjutnya dilakukan pengecekkan keabsahan data dengan triangulasi teknik yaitu berarti peneliti menggunakan teknik pengumpulan data yang berbeda-beda untuk mendapatkan data dari sumber yang sama.

\section{HASIL DAN PEMBAHASAN}

Analisis kemampuan pemahaman konsep matematis dalam menyelesaikan soal pada materi bilangan bulat kelas VII SMP Negeri 19 kota jambi. Pada penelitian ini siswa diberikan tes kemampuan pemahaman konsep matematis dengan soal uraian. Berdasarkan hasil tes kemampuan pemahaman konsep matematis yang telah dijawab oleh siswa akan diuraikan sebagai berikut.

Berdasarkan hasil tes uraian yang telah dijawab oleh siswa dapat diketahui 3 kategori kemampuan pemahaman konsep siswa. Dari 90 siswa yang mengikuti tes, siswa yang memiliki kemampuan pemahaman konsep matematis tinggi sebanyak 13 siswa, siswa yang memiliki kemampuan pemahaman konsep matematis sedang sebanyak 60 siswa, siswa yang memiliki kemampuan pemahaman konsep matematis rendah sebanyak 16 siswa.

Dari hasil tes kemapuan pemahaman konsep matematis siswa dan teknik pengambilan subjek yaitu dengan teknik Purposive sampling maka terpilihlah 2 siswa dengan tingkat kemmapuan pemahaman konsep matematis tinggi, 2 siswa dengan tingkat kemampuan pemahaman konsep matematis sedang dan 2 siswa dengan tingkat kemmapuan pemahaman konsep matematis rendah. $n$ Pelaksanaan wawancara dilakukan dengan menyesuaikan waktu siswa yang menjadi subjek penelitian.

Terdapat 6 subjek penelitian untuk diwawancarai dengan kriteria kemampuan siswa tinggi pertama dengan nilai tes 95,83, kriteria kemampuan siswa tinggi kedua dengan nilai tes 87,5, kriteria kemampuan siswa sedang pertama dengan nilai tes 75 , kriteria kemampuan siswa sedang kedua dengan nilai tes 70,83 , kriteria kemampuan siswa rendah pertama dengan nilai tes 37,5 dan kriteria kemampuan siswa rendah kedua dengan nilai tes 25 .

Dalam menyelesaikan soal nomor 1 dengan indikator menyatakan ulang konsep yang telah dipelajari sebanyak $70 \%$ siswa yang mampu menyatakan kembali konsep yang telah dipelajari sebelumnya. Dalam menyelesaikan soal nomor 2 dengan indikator mengaitkan berbagai konsep matematika secara internal dan eksternal sebanyak $61,11 \%$ siswa yang telah mampu menjawab soal dengan indikator tersebut. Dalam menyelesaikan soal nomor 3 dengan indikator menyajikan konsep dalam berbagai representasi sebanyak 45,55\% siswa yang telah mampu menyajikan konsep dalam berbagai representasi. Dalam menyelesaikan soal nomor 4 dengan indikator memberikan contoh atau kontra contoh dari konsep yang dipelajari sebanyak $65,55 \%$ siswa yang mampu memberikan contoh. Dalam menyelesaikan soal nomor 5 dengan indikator menerapkan konsep secara algoritma sebanyak 50\% siswa yang mampu menjawab soal tersebut.

\section{SIMPULAN DAN SARAN}

Berdasarkan hasil penelitian dapat disimpulkan bahwa kemampuan pemahaman konsep matematis siswa dalam menyelesaikan soal pada materi bilangan bulat kelas VII SMP Negeri 19 kota jambi. Diuraikan terlebih dahulu yaitu dari 90 siswa 


\section{$\pi$ (Phi)}

kelas VII.1, VII.2, VII.3 SMP Negeri 19 Kota jambi diperoleh tiga tingkatan kemampuan pemahaman konsep matematis siswa yaitu tingkat kemampuan pemahaman konsep matematis tinggi dengan jumlah siswa 13 siswa atau $14,4 \%$, tingkat kemampuan pemahaman konsep matematis sedang dengan jumlah siswa 60 siswa atau $66,67 \%$ dan tingkat kemampuan pemahaman konsep matematis rendah dengan jumlah siswa 17 siswa atau 18,89\%.

Kemudian dapat disimpulkan bahwa tingkat kemampuan pemahaman konsep matematis siswa dengan indikator menyatakan ulang sebuah konsep memperoleh presentase $70 \%$ siswa yang mampu menyatakan ulang sebuah konsep yang telah dipelajari, untuk indikator kedua dengan presentase $61,11 \%$ siswa yang mampu memenuhi indikator mengaitkan berbagai konsep matematika secara internal dan eksternal, untuk indikator ketiga dengan presentase $45,55 \%$ siswa yang mampu memenuhi indikator menyajikan konsep dalam berbagai representasi, untuk indikator keempat dengan presentase $65,55 \%$ siswa yang mampu memenuhi indikator memberikan contoh atau kontra contoh dari konsep yang dipelajari dan untuk indikator kelima dengan presentase $50 \%$ siswa yang mampu memenuhi indikator menerapkan konsep secara algoritma.

Dari hasil keseluruhan diatas bahwa siswa yang mampu memenuhi indikator menyatakan ulang sebuah konsep yang telah dipelajari memperoleh presentase yang paling tinggi dan sedangkan indikator yang mendapat presentase rendah terdapat pada indikator menyajikan konsep dalam berbagai representasi.

\section{DAFTAR PUSTAKA}

Arifin, Zainal. 2012. Evaluasi Pembelajaran. Jakarta: Kementrian Agama.

Arikunto, Suharsimin. 2013. Dasar-Dasar Evaluasi Pendidikan (Edisi 2). Jakarta: Bumi Aksara

Arikunto, Suharsimin. 2014. Prosedur Penelitian Suatu Pendekatan Praktik. Jakarta: Rineka Cipta

Fitriani, S. 2015. Analisis Metakognisi Siswa Tipe Melancholis dalam menyelesaikan Masalah Matematika. Proceeding Seminar Nasional Hasil Penelitian (SNHP) Conference 2015, 2015, 335-344. Jambi: Batanghari Jambi University

Fitriani, S. 2016. Analisis Kesalahan Siswa Berdasarkan Adversity Quotient Tipe Quitter Dalam Menyelesaikan Masalah Matematika. Proceeding InternationalJISE Conference 2016, 745-756. Jambi: Universitas Jambi

Hamzah, Ali. 2014. Evaluasi Pembelajaran. Jakarta: Raja Garfindo Persada

Jihad, Asep. 2012. Evaluasi Pembelajaran. Yogyakarta: Multi Persindo

Karunia Eka Lesatari dan Mokhammad, Ridwan. 2015. Penelitian Pendidikan Matematika. Bandung: Refika Aditama.

Moleong, Lexy J. 2010. Metodologi Penelitian Kualitatif. Bandung: Remaja Rosdakarya

Sugiyono. 2007. Memahami Penelitian Kualitatif. Bandung: Alfabeta. 